\title{
Governance as a Means of Legitimacy in Public Relations
}

\author{
K. Ozkan Erturk \& Elif Sesen (Corresponding author) \\ Omer Halisdemir University, Turkey \\ E-mail: elifsesen@gmail.com
}

Received: April 1, 2017 Accepted: April 19, 2017 Online published: April 21, 2017

doi:10.5296/jpag.v7i2.11024 URL: https://doi.org/10.5296/jpag.v7i2.11024

\begin{abstract}
Legitimacy emerges as a concept that explains the level of support towards the actions and procedures carried out in almost every area where the governing body and the governed relationship is found. The support of the target audience given to the actions and procedures of the organization regarding public relations would elicit positive effects in ensuring the legitimacy of the organization. For this purpose, the organization's consideration of such governance principles as clarity (openness), accountability, transparency, responsibility and consistency in its activities would reinforce its positive image in the presence of the target audience. In public relations, it is aimed to gain the support of the target audience for the actions and procedures carried out and to acquire public support for the upper administration in this respect. In this study, an evaluation is presented on the concept of governance, which is in the foreground with the principles of openness, accountability, transparency and consistency as an important means of ensuring legitimacy in public relations.
\end{abstract}

Keywords: Public Relations, Legitimacy, Consensus, Administration, Governance

\section{Heading Reconciliation Tool between the Governing and the Governed: Governance}

In a socioeconomic and cultural sense, the world is undergoing a multi-faceted and comprehensive transformation. There are four different discourses on what this transformation is. The first one is the transition from the industrial society to the information society, the second from the Fordist production to the flexible production transition, the third from the nation-state world to the globalized world, and the fourth from modernist to postmodernist thought (Tekeli, 1996: 49). As a result of such a versatile and rapid transformation process, the conditions that render administration legitimate and powerful are gradually eroding, and new quests are emerging in administerial processes (Yüksel, 2000: 149). As one of the new approaches to administrative understanding, it is possible to say that governance presents a participatory and multi-lateral administration approach. 
While the term government in English from the same root expresses the structure and functions of public institutions; the term governance refers to the ways and styles in which governments do their business (Frederickson, 2004: 7). In this sense, it is possible to say that governance is based on the participation of all the actors in the environment where the administration is concerned.

Rapid change and development experienced in almost every field of life due to globalization cause an important switch in the content in terms of understanding and institutionalization in political, social and economic situations. An important aspect of this change and development is that the relationship between the state, society and the individual changes in quality and an interactive understanding begins to prevail (Ökmen et al., 2004: 40). As a result of this change, the relationship between the state and the citizen becomes intensive, and the expectations of the citizen from the state have increased. The classical concept of public administration, which started to be inadequate in response to these expectations, has led to new administerial approaches that are dominated by governance.

Although governance emerged as a result of the quest for public administration understanding, it has also been perceived as a model over time in terms of the private sector. Different classifications can be made regarding governance. In examining the related literature, the most frequently observed types of governance are Global Governance, Public Governance, and Good Governance. Types of governance are briefly mentioned here.

\subsection{Global Governance}

Today, almost everyone is faced with a process that is thought to be a new world order, which is being restructured more or less. This process includes both economic and political qualities in accordance with its characteristics. The harmonization and reconciliation of national and international actors are important in achieving the objectives set in this model (Karaman, 2000: 43). In this environment, the results of the reforms implemented in accordance with the free market economies throughout the 1970s and 1980s have indicated that economic projects alone would fail if factors such as political legitimacy and social order conditions are not taken into account sufficiently (Yüksel, 2000: 155). It is also possible to claim that the governance phenomenon that has come to the agenda in the same period has also become globalized. In this process, global governance, which is on the agenda, has also revealed new administrative strategies proposed as an alternative to government form in a world order created by the nation-states. It has been argued that the governance concept, as well as being used to express new types of interaction between the governing and the governed, is embodied in the unconventional new administerial modes of the public and private sectors at the boundary between the government and the society.

It is possible to say that the United Nations (UN) provided the most important contribution to the development of global governance among international organizations. In the UN's development programs; legislative and executive bodies, public and private sector managements, decentralization, local governments and non-governmental organizations contribute to the development of governance in many countries (Özer, 2006: 76). 


\subsection{Public Governance}

In parallel with the transformations in the whole world, the restructuring process within the state and the multifaceted and complex interactions that determine this process require new and different approaches in the field of public administration (Şaylan, 1996: 15). However, these approaches stem from differences in the core tasks of the public sector in general. Accordingly; the distribution of income and distribution of goods and services, and the activities to preserve it have created governance approaches to managing economic rules by making arrangements in public and, especially, the private sector. Public governance is concerned with how these conditions would take place (Lane, 2000: 4).

In contemporary societies, public governance foresees not only the external administrative control of the community but also the interactional administration resulting from all the actors involved in the process. In practice, this interaction is continuous. A governance structure must be able to fully accommodate and coordinate the capability of transformation to meet contemporary administerial needs (Bozkurt et al., 1998: 274).

\subsection{Good Governance}

The concept, that began to take on shape within the framework of the power and administration problems in the countries such as Africa where a stable and settled state structure did not exist in the first place, has been shaped as a result of structural reform and improvement activities applied to the public administration in the country due to failure of 'Structural Adjustment Programs' put into effect by the World Bank. The concept of good governance emerging as a result of these activities is brought forth by a number of features. It is possible to list these basic features as follows (Yüksel, 2000: 155):

- Ensuring the safety of citizens,

- The rule of law,

- The existence of the legal state provided by judicial independence,

- Fair and accurate administration of public expenditures by public institutions,

- Existence of a political system whereby administrators can account for their actions and the governed can ask for accountability,

- The existence of transparent administration and the minimum requirements of human rights.

On the political perspective, it is possible to state that "not only the legitimacy and formally democratic administration of the state but the participation of the people in every possible field and mode of administration is possible. It is the existence of an effective, independent, transparent and auditable public administration that is aimed in administerial perspective" (Göymen, 2000: 6-7).

Governance, in this sense, means "a new kind of relationship through which a number of functions and their responsibilities are transferred from the state to civil society" (Göymen, 
1999: 72). Creation of a cohesive environment in which co-planning, co-management, and participation are possible in this policy that encompasses a large number of actors has a determining role in ensuring that the actions of the social actors achieve their intended outcomes.

\subsection{Fundamental Principles of Governance Practices}

The rules and principles in the administerial field are subject to perceptual changes over time. In governance which can be perceived as a result of the efforts to meet changing administerial perceptions, certain principles come to the forefront. These principles are included in this section of the study.

\subsubsection{Transparency}

Transparency in the administration is a concept of whether or not the flow of information is free. Clarity and transparency, which point out the openness of institutions, knowledge, and performances for those who need them, are among the indispensable responsibilities of administration. According to Aliefendioğlu (2001: 33) "The understanding of confidentiality of the countries' best interests is the cause of corruption in government". The transparency of administration appears as an important condition for governance to be achieved. The transparency principle has a major precaution since it also requires clarity in identification and implementation of policy objectives.

\subsubsection{Accountability}

Accountability refers to acting responsibly in response to criticism and requests toward authority and responsibilities, as well as to be able to respond to the related persons due to the authority and responsibilities of an organization. One of the most important features of the rule of law is the emphasis that the governing body must be responsible for the governed (Aliefendioğlu, 2001: 33). The accountability principle of governance emphasizes the need to revise attitudes and behaviors in response to criticism and requests from those units, in response to those who are responsible for the authority and responsibility of those employed by an organization. In accordance with this principle, the employees are also obliged to take responsibility for any failure in their work performance (Özer, 2006: 80). The decision-makers of either public organizations, private enterprises, or non-governmental organizations should be accountable to their public and corporate stakeholders.

\subsubsection{Participation}

It is imperative that those who are governed within democratic structures participate in decision-making processes through intermediary bodies or agencies that directly or indirectly represent themselves. While policies can be developed through active participation of the governed directors, reconciliation between different interests can be achieved, and at the same time, the governed may have the ability to act in terms of common interests beyond their own.

\subsubsection{Rule of Law}


In general terms, the concept of the rule of law means that the law is pre-established, declared, general, regular, definite, applicable to all, clear and understandable. In this sense, the rule of law provides that the rights and freedoms of the citizens be under legal protection and are not left to the mercy and discretion of the governing body (Gözlügöl, 2013: 1432). Within the framework of this principle, it is emphasized that institutions must act within the legal boundaries that are formed in a fair manner and that individuals must act in accordance with the laws.

\subsubsection{Efficiency}

Regarding governance, the tendency to evaluate the decision-making system on the problem-solving potency scale is dominant. In this approach, the effectiveness is defined as the criterion for abolishing or mitigating the problems about the construction of the international system (Kesim and Petek, 2005: 46). It is possible to discuss the concept of efficiency from both economic and political perspectives. Technically, efficiency refers to the use of public resources by competent public bureaucracies for the fulfillment of public demands for services (Palabiy1k, 2004: 69). The importance of the efficiency concept is increasing day by day as due to the decline of the resources utilized in the provision of public services over time. When assessed from this aspect, administrative efficiency can be regarded as the ratio of the resources utilized as an administerial value to the results obtained (Balc1, 2005: 27).

\subsubsection{Equality}

In the meaning of the right that everyone is entitled to fair treatment and equal opportunity without discrimination in terms of their characteristics such as race, language, religion and gender; equality describes the fostering of opportunities that allow everyone to move to better levels by maintaining his or her well-being and happiness in their unique circumstances (Aşkın, 2003: 108). Within the framework of the equality concept, the administration must provide equal opportunities for people to take part in political, economic and social fields; provide access to resources; and make people a strong element of social and economic life (Güler, 2003: 109).

\section{Scope, Functions and Objectives of the Public Relations Activities}

Although public relations is a relatively new concept as the sum of planned activities aiming at organizing and maintaining the affirmative relationship between the organization and its target audience, there are occasional uncertainties in terms of its origin, scope, purposes and functioning. It is also difficult to say that there is a complete agreement on the definition of the concept. Nonetheless, a brief examination of the public relations activities regarding their scope, function, and purposes would contribute to comprehend the complexity and uncertainty regarding different aspects.

\subsection{Scope of Public Relations Activities}

It is possible to relate the difficulty of defining public relations to the existence of many different definitions in the related literature. The total number of descriptions made about 
public relations is over 400 nowadays. Each definition of public relations explicates the concept by considering different aspects of it. While some of these definitions deal with public relations in terms of administration, some draw attention to the aspect of interaction and some to its nature of adaptation. For example, according to a definition, public relations is considered as "the art and science of achieving harmony with the environment through mutual understanding based on accurate and full information" (Black, 1993: 14). According to another definition, public relations is perceived as "cooperation between the organization and the target audience in order to adapt to each other's needs" (Lesly, 1991: 5). Common features of the definitions that try to explain public relations appear as an emphasis on planned communication efforts aimed at establishing and maintaining mutual understanding, trust, and harmony between the organization and the target audience.

It would be hard to say that the role and purpose of public relations in the present capitalist system is fully grasped. Considering today's market conditions, public relations which is inevitable in terms of almost every institution can sometimes be confused with various applications. The main objective of public relations, which differs from lobbying, marketing, advertising and journalism in many respects, is to provide a suitable environment for increasing the sale of the goods or services instead of selling them (Tortop, 1993: 46). Among the many definitions related to the public relations activities, the one on which a consensus was reached at the $1^{\text {st }}$ World Public Relations Congress in Mexico City in 1978 is accepted as the most common definition in the international arena. According to this definition, "public relations activities involve the art of analyzing trends, predicting outcomes, advising the leader of organizations and implementing planned activity programs for both the organization and the public interest" (Schukies, 1998: 16).

When the common points of public relations definitions are considered, it can be said that the emphasized aspects are usually related to the scope, function, and purpose of public relations practices. In this sense, the applications that are referred to as public relations describe more than one activity or communication function. As a practice based on communication, the main purpose of public relations is to create an atmosphere of compromise, understanding, trust and tolerance between the organization and the target audience. Regardless of the way in which public relations is defined, the ultimate goal is closely related to the satisfaction of the target audience (Işık, 2013: 8).

When assessed in an administerial sense, public relations activities predominantly strive to provide a relationship of mutual understanding and consensus between the governing and the governed parties. In most democratic countries, the acquisition of public trust and public support is in parallel with the administrative success. In the acquisition of public trust and public support, it is necessary for the administration to demonstrate its justness and legitimacy in the presence of the governed by making the effective communication system work. In this respect, important tasks devolve on public relations.

\subsection{Basic Functions of Public Relations}

The researchers who compiled the present definitions of public relations by evaluating more than four hundred different definitions since the beginning of the 1900 s described it as "an 
administrative function that helps to establish and to maintain mutual communication, understanding, acceptance and cooperation between the organization and the target audience" (Paksoy, 1999: 23-24). In this sense, public relations helps the administration to act in accordance with responsibility towards the public by considering public opinion. At the same time, the administration emphasizes its responsibility to act for the public interest principle. It helps the administration to follow social changes and warns it against various social developments. In addition to all these, the activities are carried out through a meaningful and honest communication and research instrument. It is possible to list the basic features and functions of the public relations in terms of organization as follows (Çamdereli, 2000: 18-19):

- Public relations is essentially an administrative function,

- Public relations is a communication process,

- Public relations is an effort to influence the public opinion,

- Public relations establishes mutual relationships among the organizations and the target audiences,

- Public relations involves activities that are organized in terms of social responsibilities.

\subsection{Objectives of Public Relations}

The definitions of widespread public relations in the literature point out that the main purpose of public relations is to establish positive relations, efficient communication, and interaction with the environment of institutions or organizations. Public relations activities are realized within a long period. Nevertheless, one of the main aims of public relations activities that are planned and realized over a long period pertaining the positive identity and indirect profitability to be acquired by the organization in the long-term (Çamdereli, 2000: 20-21).

It is possible to claim that the public relations activities aim at establishing privileged relations with the various audiences of the organizations by rendering the identity, the goods or the service valuable. In addition to these, it is possible to list the objectives of public relations as follows (Tortop, 1993: 10):

- Enlightening the people to ensure that they embrace the works,

- Creating positive public behaviors towards the administration,

- Facilitating the work of the people in relation to the administration (facilitating consultation, giving information),

- Collecting public information to increase the likelihood of judicious decisions,

- Providing public information (such as traffic laws and prohibitions) to ensure compliance with the law and regulations,

- Ensuring that services can be seen more quickly and easily by providing cooperation (such as school, hospital, road construction, school-family meetings), 


\section{$\Lambda$ Macrothink}

Journal of Public Administration and Governance

- Evaluating the laws, bylaws and other designs prepared by the wishes, recommendations, suggestions and complaints of the people to eliminate the problems,

- The purpose of public relations is to try to respond to the private and public interests and to create a sense of social responsibility by respecting everyone's personality.

\section{Governance as a Means for Providing Legitimacy in Public Relations Activities}

Legitimacy has become an important phenomenon in terms of public relations practices over time. The justification of the actions carried out in almost every area where the governing body and the governed relations are concerned should be questioned by the governing body and be explained by the governed. In the case of such a mutual responsibility, it is essential to establish and maintain a competent communication system. Through communication, uncertainties between the governing body and the governed can be removed by avoiding possible doubts and worries and ensuring a secure relationship. For the organizations, the provision of legitimacy for the actions and transactions carried out in the eyes of the target audience would strengthen the possibility of ensuring the positive image about the organization's actions and transactions and public support.

\subsection{Legitimacy Concept and Sources of Legitimacy}

As the result of the search for meanings related to legitimacy concept, it is possible to see that it appears as a phenomenon that must be solved and clarified firstly in almost every area of life wherever human society and political power exist. Those who hold the political power in some way are obligated to give meaningful explanations of the reasons for their being in power, their behaviors and the consequences of their behaviors. Almost every social system has to face the question of legitimacy with certainty and to evaluate the relevance of the environment at certain intervals whether or not they deserve the interest shown to them (Atiker, 1998: 119). In this sense, legitimacy is not a problem solved once it is obtained, and not a right that has been acquired forever. One must keep in mind that it takes continuous effort to be acquired and retained.

Legitimacy that can be considered as a search for meaning in its essence; emerges as a question that must be answered first and as a problem to be solved foremost in every area where human beings, human communities, political power, and movement are present. Legitimacy, at first glance, seems to be a subject that falls into the field of law, but it is rather a matter that transcends the field of law to be understood and comprehended beyond the law (Kapani, 1998: 81).

Organizations adopt and implement numerous plans, policies, and strategies to compete within their fields, to attain a certain area of power, to achieve the targets they aim at and to make themselves effective and productive. As a result of these practices, the legitimacy crisis is on the rise, and the reason for the existence of the organization becomes debatable when the organizational interest - social utility balance is noticeably deteriorated for the organization. Therefore, the institutions within societies with pluralistic qualities where different interests are represented have to explain their own acceptable as well as institutional 
interests. The ones under the influence of a particular power or organization wish to know clearly what type of benefits they have from that interaction, and such a flow of information would only be possible through the communication channels that are created between the organization and its environment. The effort of creating these communication channels is, in essence, not another activity different than the public relations (Biber, 2009: 141).

\subsection{Place and Importance of Legitimacy in Terms of Public Relations Activities}

Almost every type of organization is basically established in order to gain power. However, it should be explained by using valid methods and techniques how to use this power and how the benefits of the society are provided by this power, and whether or not the organization fulfills its responsibilities towards the society (Biber, 2003: 66-67). Organizations have a legal dimension of their existence, but it is impossible to talk about the basis of a legitimacy that cannot respond to questions about their duties and responsibilities, and social approval will be more difficult.

It can be said that one of the main objectives of public relations activities in terms of public administration is to develop a positive image towards governance in order to ensure productivity and success in service. Today, as a result of globalization, the criterion of success and legitimacy has changed in terms of public administration. "The labyrinths of the State must now be explained, interpreted and illuminated. The citizens have less time and attention left to spare the State. Today's citizen desires a communication system that will create the common voice and understanding of ancestors for centuries in the village congress" (Cutlip and Center, 1971: 531).

It can be argued that a great majority of the functions of public relations be of great importance in terms of providing organizations with legitimacy that are formed for different purposes such as indirectly obtaining power and profits. Through the activities related to public relations, it is possible to find the opportunity to express itself, to give a perspective to the environment and to create positive attitudes and behaviors towards the institution.

Ensuring the legitimacy of the organization becomes more important in the global competitive environment. Within the process of globalization, the possibilities of accessing and disseminating information have increased due to improvements in communication technology. At this point, as much as the positive information about an organization or its goods and services, the rate of dissemination of negative and abusive information would be high. In a competitive environment with such rapid development and transformation potential, efforts are made to ensure the legitimacy of associations through public relations activities. The ability to provide the organization or its goods/services with legitimacy has a major role and importance for the continuity of the organization in the globalization process. Therefore, it is possible to claim that public relations has an important power and influence at the point of providing a consensus between the organization and the target audience in the process of globalization through legitimacy. Ensuring legitimacy of organized actions and transactions in the presence of the target audience would facilitate reconciliation between the organization and its environment. In this sense, providing legitimacy in public relations is also vital and necessary in terms of reconciliation of the organization with its environment. 
Public relations contributes to the continuity of the system regarding providing support to public policies and preventing the emerging problems from becoming crises and being a part of the political system with ideological dissemination and practices to justify government policies. Political organizations cannot sustain their existence for a long time without having certain support, that is, legitimacy. Public administration, which integrates social goals, is a part of the political process and public relations is important to the point of telling the public why it is done. Public relations within the public administration system also serves to provide legitimacy and support to the political-administrative authority. Regarding public administration, it is very important to ensure and maintain legitimacy at national and international level. The theory of liberal democracy positions public relations as a means of providing legitimacy to be applied in the context of pluralist democracy. This approach, which considers public relations as an efficient means of improving administration and ensuring organizational productivity, does not place much emphasis on the ideological structure and hegemonic discourse of public relations.

\subsection{Contribution of Governance Principles to the Legitimacy Perception in Public Relations Activities}

Public relations is closely related to legitimacy as whole planned activities undertaken with the aim of establishing a communication-based relationship between any organization, person or establishment and their target audience within the framework of mutual trust, understanding, and tolerance. The organizations, establishments, persons or entities have target audiences that are affected by actions and operations for which they are responsible. Establishment of mutual understanding and trust between the target audience and the organization is closely related to the fact that the actions and transactions are correctly understood and adopted by the target audience. At this point, the public support for the activities of the organizations would increase. The likelihood of having a positive image for the organization with public support would also increase. It is possible to list the known basic principles of public relations activities, which play an important role in establishing an accurate, secure and healthy communication between the organization and the target audience:

- All activities should be transparent,

- All activities must be based on honesty,

- Public relations should be considered as two-way communication based on the relationship,

- Public relations should reflect the facts,

- Public relations involves specialty,

- Public relations is a continuous work,

- Professional ethics rules in public relations must be abided by,

- Public relations activities must be based on scientific principles (Alikılıç and Onat, 
2007: 901).

The principles listed here include the common features of activities carried out in terms of public relations. The common aspects of these principles indicate that public relations activities provide clarity, transparency, honesty and stability. In this sense, it is possible to consider some common aspects between legitimacy and governance principles in public relations as follows (Ertürk and Berkman, 2016: 70):

Transparency: Administrative transparency is crucial in terms of provision of public support to actions and operations carried out in the presence of the governed. In this sense, transparency is given importance in the activities and transactions carried out in public relations and the information is shared with the public, and it contributes to the legitimacy of the organization. Every organization should openly share information about its activities with the public. In this way, while the public support for the activities of the organization increases, support for the establishment and maintenance of the positive organization image would be supported.

Accountability: It is crucial for an organization to be able to account for units that are responsible for its activities, ensuring the legitimacy of its activities. Being accountable is also a broad concept, including the responsibility of an organization to the public. Openness and honest administration as the basic principles in public relations also oblige the responsibility of the organizations for the counterparts in the activities carried out. Being accountable would also provide positive contributions to the justification of the publicly carried out activities.

Participation: The ability to incorporate internal and external targeting elements into an organization's decision-making process and the ability to conduct co-management / decision-making is important to ensure that public support is provided for activities carried out by the organization. Any contribution of the elements that constitute the target audience which can affect the organizations with actions and operations would increase the public support towards the organizations.

Rule of Law: Where there is a societal position of reciprocity, such as the governing-governed or the buyer-seller, the protection of the right is needed in recognizing the rule of law. Here, the law assures, as a superior decision-maker, that the rights are protected. In public relations, lawfulness and superiority of law also stand out as important factors in securing public support for the actions and operations carried out.

Efficiency: Utilization of current resources and facilities in the most efficient way possible without any waste in the actions and transactions carried out explains efficiency concept. Regarding governance, the use of public resources in the most efficient and productive way brings forth the emphasis on the careful attention must be paid to the organization's activities. The organization's respect for its environment in terms of public relations would contribute to increased public trust for the organization.

Equality: Careful attention to equality in the activities carried out by the organization is beneficial in terms of strengthening the trust and positive image of the target audience. The 
importance given to equality in decisions and practices of the organization's top management regarding public relations would be effective in increasing the trust of the internal target audience in the carried out actions and transactions. Likewise, the importance given to equality and equity by the organization in external target audience's opinion would be effective for contributing to the activities carried out and the favorable image of the organization.

\section{Conclusion}

The main problem with legitimacy is the question of what the foundation of the governing power would be. Legitimacy, as the assurance of almost all forms of political administration, is an attribution that must constantly be reestablished or acquired. In this respect, it would not be wrong to say that the legitimacy of the administration is based largely on compromise and consensus with the governed. For this reason, all administrations try to legitimize their authorities and themselves by various means and instruments. Public relations is one of those instruments.

Among the administrative purposes of the public relations with the ultimate goal of reconciling between the organization and the target audience, the establishment, and maintenance of a relationship between the governing and the governed within the framework of mutual consensus loom large. This goal is also among the main objectives of governance. This is because, governance, as the combination of the terms "government" and "communication", ensures a long, proper and healthy communication between the administration and the governed. Transparency, accountability, and participation, which are among the basic principles of governance, closely relate to the aims and objectives of public relations.

\section{References}

Aliefendioğlu, Y. (2001). Law, Rule of Law and State of Law. Journal of Ankara Bar (Ankara Barosu Dergisi). 4(1). 29-68.

Alikılıç, Ö., Onat, F. (2007). Corporate Blogs as a Public Relations Tool. Journal of Yasar University. 8(2). 899-927.

Aşkın, D. M. (2003). Equity and Good Governance: Key Elements of Good Governance. Ministry of Finance Department of EU and Foreign Affairs. Ankara.

Atiker, E. (1998). Modernism and Mass Society. Ankara: Vadi.

Balc1, A. (2005). Reconstruction of Public Administration System with Perspective of Turkey-EU Relations. Journal of Public Administration (Amme İdaresi Dergisi). 38(4). 23-37.

Biber, A. (2003). Basic Concepts in Public Relations. Ankara: Nobel.

Biber, A. (2009). Review on Past, Present and Future of Public Relations. Journal of Gazi University School of Communication (Gazi Universitesi İletişim Fakültesi Dergisi). 29(2). 137-144. 
Black, S. (1993). The Essentials of Public Relations. London: Kogan Page.

Bozkurt, Ö., Turgay, E., Sezen, S. (1998). Public Administration Glossary. Ankara: TODAIE.

Cutlip, S.M., Center, A. H. (1971). Effective Public Relations. NJ: Prenctice Hall.

Çamdereli, M. (2000). Outlines of Public Relations. İstanbul: Çizgi.

Ertürk, K. O., Berkman, A. N. (2016). Corporate Governance as a Communication Policy in Two-Way Symmetrical Public Relations Model. Journal of Omer Halisdemir University Faculty of Economics and Administrative Sciences (Omer Halisdemir Universitesi İktisadi ve İdari Bilimler Fakültesi Dergisi). 9(2). 61-73.

Frederickson, H. G. (2004). Whatever happened to public administration? Governance, governance everywhere, In E. Ferlie, L. E. Jr. Lynn \& C. Pollitt (Eds.), The Oxford Handbook of Public Management (pp. 282-304). Oxford: Oxford University Press.

Göymen, K. (1999). Evolution of Participation in Turkish Local Government: Governance Dynamics in Centralist State. Journal of TODAIE (Institute of Public Administration for Turkey and the Middle East). 32(4) .64-77.

Göymen, K. (2000). Local Governments and Governance in Turkey: Requirements, Suggestions, Orientations. Modern Local Government Journal (Çağdaş Yerel Yönetimler Dergisi). 9(2). 3-18.

Gözlügöl, S. V. (2013). Rule of Law through International Law. Journal of Gazi University School of Law (Gazi Üniversitesi Hukuk Fakültesi Dergisi). (17)1. 1423-1453.

Güler, A. B. (2003). Governance: All Power to Capital. Praksis. 9(1). 93-116.

Iş1k, M. (2013). What is Public Relations or not? Konya: Eğitim.

Kapani, M. (1998). Introduction to Politics. İstanbul: Bilgi.

Karaman, Z. T. (2000). Progress in Management Strategies. Turkish Administration Journal (Türk İdare Dergisi). 426. 5-42.

Kesim, K., Petek, H. A. (2005). Review of Turkish Public Administration Reform within the Frame of European Commission's Good Governance Principles. Journal of Public Administration (Amme İdaresi Dergisi). 38(4). 39-58.

Lane, J. E. (2000). New Public Management. London: Routledge.

Lesly, P. (1991). The Nature and Role of Public Relations, In P. Lesly (Eds.), Lesly's Handbook of Public Relations and Communications (pp. 3-19). Chicago: Probus Publishing.

Ökmen, M., Baştan. S., Y1lmaz, A. (2004). New Approaches in Public Service and Local Government as Governance Factor. In A. Y1lmaz, M. Ökmen (Eds.), Public Administration. Ankara: Gazi.

Özer, M. A. (2006). Notes on Governance. Court of Account Journal (Sayıştay Dergisi). 63(1). 59-89. 
Paksoy, A. (1999). Public Relations Practice in Turkey. İstanbul: Rota.

Palabiyık, H. (2004). Conceptual Explanation on Transition to Governance from Adminstration. Journal of Public Administration (Amme İdaresi Dergisi). 37(1). 63-85.

Schukies, G. (1998). Quality for Customer Satisfaction in Public Relations, In G. Schukies, A. Unver, G. Ozen (Eds.), Quality, Customer Satisfaction, Public Relations: New Directions for Organizational Communication (pp.1-20). IPRA, İstanbul: Rota.

Şaylan, G. (1996). Public Administration as an Independent Discipline. Journal of Public Administration (Amme İdaresi Dergisi). 29(3). 3-16.

Tekeli, İ. (1996). On the Reasons of Development of Governance with Parallel to Administration. Social Democratic Change (Sosyal Demokrat Değişim). 2(3). 45-54.

Tortop, N. (1993). Public Relations. Ankara: Yarg1.

Yüksel, M. (2000). On Governance. Journal of Ankara Bar (Ankara Barosu Dergisi). 3(1). 145-159.

\section{Copyright Disclaimer}

Copyright for this article is retained by the author(s), with first publication rights granted to the journal.

This is an open-access article distributed under the terms and conditions of the Creative Commons Attribution license (http://creativecommons.org/licenses/by/4.0/). 